\title{
FISCAL POLICY IN PAKISTAN: THE POLITICS OF DISTRIBUTION IN A CHANGING LANDSCAPE
}

\author{
Muhammad Abdullah \\ Assistant Professor, Department of Economics, \\ University of Sahiwal, Sahiwal. Pakistan \\ mabdullah@uosahiwal.edu.pk \\ Ayza Shoukat \\ Lecturer, Department of Economics, \\ University of Sahiwal, Sahiwal. Pakistan \\ ayzashoukat@uosahiwal.edu.pk \\ Muhammad Gulzaib Chaudhary \\ Ph.D. Scholar and Lecturer, \\ GC University, Lahore. Pakistan \\ gzb_ch@hotmail.com
}

\begin{abstract}
Fiscal policy aims primarily at controlling aggregate demand but in developing countries, the aims and objectives of fiscal policy are much extended. Due to the important role of fiscal policy in maintaining macroeconomic stability, it must be carefully designed in a way to accelerate investment, on one hand, and on the other hand, it must redistribute the resources from socially less desirable to more desirable investment channels. The efficient allocation and distribution of resources can help to narrow the income gap and economic discrepancies among different social groups. Instead, if the resource distribution is politicized, the whole picture would be reversed. The present study analyzes the objective of equitable distribution of income and wealth with the practice of political distribution in Pakistan. Despite the objective of equitable distribution of income and wealth, political actors from federal and provincial governments spend public funds to achieve political goals rather than on development-oriented programs. These investments secure the political interests of those actors. Also, the selection of projects and the provision of subsidies are politicized.
\end{abstract}

\section{INTRODUCTION}

Fiscal policy is one of the fundamental ingredients for sustained development with equitable distribution of resources both socially and economically. It is unnecessary to quote the importance of just distribution of income and wealth in a society with the perspective of development. Particularly, for transitional economies, economic inequality occurs at primitive stages of growth and tends to lower with advanced stages of growth. The efficient use of fiscal policy can transform the situation even at initial levels. In Pakistan, the situation of inequality is much worse than in other developing countries. There could be many reasons for this inequality but weak fiscal execution and the political economy of distribution through fiscal policy decisions are the key elements (South Asia Economic Focus, 2017). The fact is that the power is concentrated in the hands of a few political actors and decisions regarding redistribution are overshadowed by the political interests of individuals.

There exists anxiety in Pakistan over the issue of unjust distribution of income and wealth. The absence of fair distribution is incurring socio-economic cost in the form of social turmoil, political imbalance, and social dispersion (SDPI, 2013). Also, the rising concern of economists towards a fair fiscal policy is soaring in Pakistan. According to Ahmed et al., (2011), "Fiscal policy is not redistributive in Pakistan". Behind this, there are many reasons like public revenue is beneath the desired level (i.e. 
total public revenue was approximately $9.8 \%$ of total GDP in 2014 and at the lowest level as compared to other developing countries (SDPI Policy Briefing, 2015)). On the other hand, a large set of income and wealth is not taxed (i.e. real estate). Although we have been following a progressive tax structure, the exemption of taxes in various agriculture and fewer services sector are sabotaging the whole system of taxation (Pakistan Economic Survey, 2014). Besides, a large number of tax evasions are widening the revenue expenditure gap in Pakistan. Further, the formal transactions which are to be taxed but remain untaxed, have induced a 79\% of tax gap (SDPI Policy Briefing, 2015). This utter level of revenue gap yields lower spending on basic public services like health, education, infrastructure, and water and sanitation. Moreover, to meet the deficit, the government is continuously borrowing (both internally and externally) and public debt levels are increasing alarmingly by each day. On one hand, this borrowing is dreadful for local investors as limited funds are left for their borrowing in local commercial banks and on the other hand, high public borrowing is justifying copious future tax burdens (State Bank of Pakistan, 2013).

According to Drèze \& Sen (2015), the effect of sustained growth on the living conditions of the general public partially depends on the decision of income distribution and completely depends on the idea of improved public revenues through non-polarized policies of central authorities. The current study also intends to shed light on the politicized fiscal policy in Pakistan at both the federal and provincial levels. The study is organized as section 2 deals with the scope of fiscal policy, section 3 describes the political economy of fiscal policy in Pakistan, section 4 briefly discusses the fiscal concerns in changing landscape with a special focus on CPEC and finally, section 5 discusses some necessary elements for a just fiscal distribution of resources.

\section{SCOPE OF FISCAL POLICY}

The ambit of fiscal policy considers federal as well as provincial governments. Also, local governments came under this category as they are formed under elected governments. According to Pasha (2014), the fiscal policy includes mobility of resources, current and development spendings, transfer of funds from central to the provincial government and deficit financing in case of revenue deficiency. The below Figure-1 explains the heads of fiscal policy in detail.

\section{Figure 1. The Ambit of Fiscal Policy}

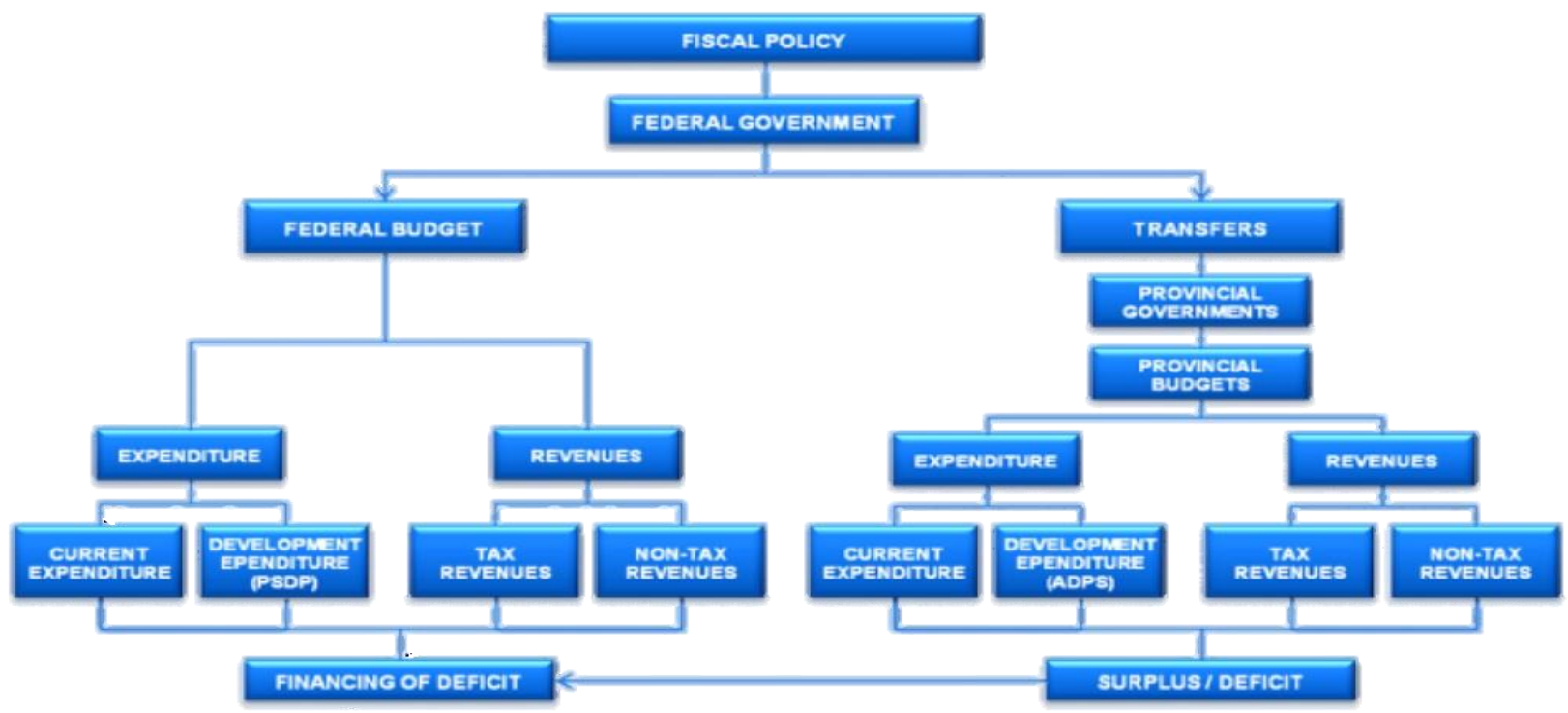

Source: Pasha (2014)

Pakistan follows a centralized revenue scheme. The federal government acquires the revenue from major revenue sources and then allocates these revenues among sub-national governments. This allocation of resources among subnational/provincial governments is based on a specific criterion called 
the National Finance Commission (NFC). Then, provincial governments redistribute these resources among local governments. NFC is ought to be delivered every five years, but the history tells a different story. We are able to deliver only a few successful NFC awards since the inception of Pakistan. NFC is a formula-based resource distribution scheme which is formulated by assigning different weights to each component. There are four main components of NFC; population $82 \%$, poverty $10.3 \%$, revenue collection $5 \%$ and inverse population density $2.7 \%$ has been assigned in $7^{\text {th }}$ NFC award (SBP, 2010). Before $7^{\text {th }}$ NFC award, population was the only criteria of distribution of resources. The formula-based resource sharing schemes like NFC are designed to ensure the efficient delivery of resources among subnational governments. But in the case of Pakistan, the formulation of NFC is alleged due to political influence. This is because the formulation of NFC is not done by the experts (i.e. statisticians or economists) rather political actors. Consequently, the stronger group gains the lion's share of resources.

\section{FISCAL POLICY IN PAKISTAN: THE POLITICS OF DISTRIBUTION}

Pakistan is currently facing inequality of distribution in terms of income, wealth (land, assets, property, etc), employment opportunities, living standards, food security, and human development. Fiscal consolidation with dreadful political practices can provide a possible explanation for these unjust distributions. Although, the formula-based distribution of resources is adopted in many economies (like Nigeria, India, Japan, Brazil, etc.) to avoid political manipulation yet political actors find a way to influence it (Calderia, 2011 \& Baneful, 2011). The important aspects of the political economy of distribution can be many but we are focusing on the financial considerations of political economy. In the case of Pakistan, the followings are most significant.

\section{The Integration of Control and Power}

Power is centralized in Pakistan and the two main pillars of the establishment are civil bureaucracy and military. These two pillars have involved a pact that ascertains the status of Pakistan as a 'Security Land' despite an emerging economy (Hussain \& Hussain, 1993). This neurotic relevance for protection has strengthened the view of centralization of power and decentralization is perceived as losing control, security, and authority. Complying with the rule of power and control, the subnational governments are power deficient. These subnational governments look up to the central government for resource allocation and funds transfer. Further, they are not fully autonomous to use fiscal powers. This structure implies the power imbalance in Pakistan where the federal government is dominant in revenue collection rather than public spending (Ahmed \& Baloch, 2014). Table-1 has displayed the percentage share in revenue and expenditure of different levels of government in Pakistan over history.

Table-1 has explained the revenue collection and expenditure scheme between the center and subnational governments. The statistics presented are self-explanatory. There lies a controversy over the opinion that sub-national governments have flourished in terms of resource allocation during the dictatorship in Pakistan. Pakistan has celebrated its $74^{\text {th }}$ Independence Day in 2021 and out of 74 years, Pakistan remained under military rule for more than 30 years. During the military regime, the hollow shell of empowered local governments lies on a large number of small governments which creates a feeble system. These small units of the federation were handy for the military government in two ways; on one hand, they were weak alternatives of democracy and on the other hand, they were the least warning to the military government (Pasha, 2014).

Table-1. Revenue Expenditure Share of Federal and Provincial Government (percentage)

\begin{tabular}{|l|c|c|c|c|}
\hline Years & $1979-80$ & $1989-90$ & $1999-2000$ & $\mathbf{2 0 0 9 - 1 0}$ \\
\hline \multicolumn{5}{|c|}{ Percentage of Revenue } \\
\hline Share of Federal Government & $88 \%$ & $90 \%$ & $89 \%$ & $88 \%$ \\
\hline Share of Provincial Government & $12 \%$ & $10 \%$ & $11 \%$ & $12 \%$ \\
\hline
\end{tabular}




\begin{tabular}{|l|c|c|c|c|}
\hline \multicolumn{5}{|c|}{ Percentage of Expenditure } \\
\hline Share of Federal Government & $80 \%$ & $77 \%$ & $76 \%$ & $72 \%$ \\
\hline Share of Provincial Government & $20 \%$ & $23 \%$ & $24 \%$ & $28 \%$ \\
\hline
\end{tabular}

Source: State Bank of Pakistan, 2010

This principle of power consolidation also applies to assigning different functions to central and provincial governments. For instance, the constitution of 1973 comprises two lists of functions; one of them is the Federal legislative list (which contains functions assigned to central government) and the other one is the Concurrent list (functions that can be performed by either central or provincial government or by both governments). These Concurrent functions are related to planning, population and basic welfare, ecology and environmental degradation, trade and industry, energy, social security, labor unions, and zakat. Practically, the central government has already displaced many of the functions which the provincial government could perform (Ahmed \& Khan, 2014).

Also, in the revenue-expenditure scheme of the central and provincial governments, there exists a discrepancy in Pakistan as compared to similar economies. For instance, in 2010, provincial governments generated 12 percent of total revenue and public spending was 28 percent during the same year (State Bank of Pakistan, 2010). These shares in revenue and expenditure are fairly small as compare to a neighboring country, India. During the same year, 2010, the average share of each state in India was around $30 \%$ where expenditure share was nearly $35 \%$.

In 2008, when the democratic government was back after a long military regime of Musharraf, there was the transfer of power from federal capital to provincial capitals with the implementation of the $18^{\text {th }}$ amendment through the $7^{\text {th }}$ NFC award. Some important features of the $7^{\text {th }}$ NFC award include the autonomy of provinces over sales tax on services, eliminating the Concurrent list of functions and shifting all the functions to the provincial government, and finally increasing the provincial share in the divisible pool by 57.5 percent (Khawaja \& Din, 2013). Although, the success of the $7^{\text {th }}$ NFC was a step towards decentralization, the power in the hands of political leaders banged in response. In this regard, the role of civil bureaucracy was significant which encourages the centralization of power. Soon, the functions in the Concurrent list have been replicated in the name of cooperation and coordination. More precisely, the preceding government of PML-N in 2013, propagated for power integration. Besides, in two major provinces, KPK and Sindh, the opposite parties were in power (Pasha, 2014). This tension between the federal government and opposite provincial governments has created political anxiety. The new democratic government of PTI took the charge in 2018 and has been highly criticized by the opposition for their poor economic performance in two years (major economic indicators are persistently declining while poverty, inflation, and unemployment are rising). There could be many reasons for this downfall including restricted economic activity due to Covid-19 but still, the political violence is volcanic, and the country is currently under political turmoil. According to Pasha (2019), serious political hazards are attached to the strong instrument are immediately required to bring back the economy on the road to sustainable development.

\section{The Acquirer of Subsidies}

Several subsidy heads are disguised in nature but put a heavy monetary cost over either federal or provincial budget or both. These subsidies are not much realized by the general masses (Beatrice, 2017). Here are some of the examples of these subsidies discussed in detail:

\section{The Irrigation Subsidy}

The irrigation charges are too undercharged as compare to the original cost. Besides, the subsidized price, irrigation is benefiting the large farm owners. The real cost of Abiana is 150 billion Pakistan rupees and the irrigation charges only compensate $9 \%$ of the original cost (SPDC, 2014). Moreover, the introduction of subsidies under the high-efficiency irrigation system (HIES) offers a 60 percent subsidy. In addition, 
concessional prices of the LASER Land Leveling unit and the introduction of the solar system at HIES are offered to farmers at very cheap prices. Although, agriculture is said to be the backbone of Pakistan yet, these subsidy schemes are incommensurately benefiting the large farmers only. Also, these subsidized prices of water are encouraging the uneconomical use of water resources as well as the high monetary cost for federal or provisional exchequers at the same time. This cost is significantly high when Pakistan has already been declared a water-stressed country (UNDP, 2017). Likewise, the Pakistan Council of Research in Water Resources (PCRWR) has discouraged the negligence of authorities over water resource management in Pakistan. PCRWR also warned that Pakistan may dry up in 2025 and water scarcity would be further intensified (Qureshi \& Ashraf, 2019).

\section{Roads and Highways}

Another important but veiled subsidy is a subsidy on roads and highways. The repeated tolls and amortization of roads and highways are significantly large i.e. more than 120 billion Pakistani rupees. Instead of high incurring costs, a couple of highways are charging tolls. Moreover, these tolls are taking very low prices despite the high maintenance cost. According to SPDC (2012), the total subsidy offered at toll plazas is more than 90 percent of the entire cost. A policy of more progressive toll charges for the private transporters would be helpful to maintain the pace of an efficient transportation system.

The other subsidies which are to be monitored and managed are including a subsidy for higher education, tariff differential subsidy to the power sector, and food subsidy. The chronic emergence of the political economy of subsidies is that a large proportion of these concessions are acquired by the fortunate rich people and the deprived population is still suffering. Due to the political interests of the entities, the purpose of general welfare through subsidies is victimized and welfare outcomes are not fully accomplished.

\section{The Special Case of Sacred Cows}

The politics on the expenditure side is a matter of pivotal concerns and the exclusiveness of the 'sacred cow'. In the history of Pakistan, the role of the sacred cow has been played by the military administration (Pasha, 2013). In convention, the defense budget is not subject to be questioned and even not discussed during parliamentarian meetings.

Over history, defense expenditures are increasing by each year. In the 2017-18 federal budget, the defense budget is 7 percent higher than the previous year. The total budget was announced as 4.7 trillion Pakistani rupees out of which more than 19 percent has held for defense affairs and services. Besides the operational expenses, salaries, remuneration expenses, physical assets spending, and civil works expenditures, the fiscal expenditures for payment of pensions of retired army officials are separate from the budget allocated for defense services (Highlights of Budget, 2017-18). Also, the military officer has a usual $10 \%$ increment in the salaries under the head of 'special allowance' in the budget of 2017. Further, there is a fixed allowance of 8000 rupees per month for the Jawans of the military, and both special allowance and fixed allowance are not included in the defense budget but are classified separately. Moreover, the usual $10 \%$ ad hoc increase is an additional cover for military officials along with the special allowance (Ministry of Finance, 2017). While observing the tax system in Pakistan, there are a bunch of holes in our taxation system. These holes are special treatments in terms of tax payment, tax exemptions, privilege based on rank, and tax concessions. Following Figure- 2 represents the exemption from indirect taxes during previous years. 
Figure-2. Tax Exemptions (Indirect Taxes) in Pakistan (in billion rupees)

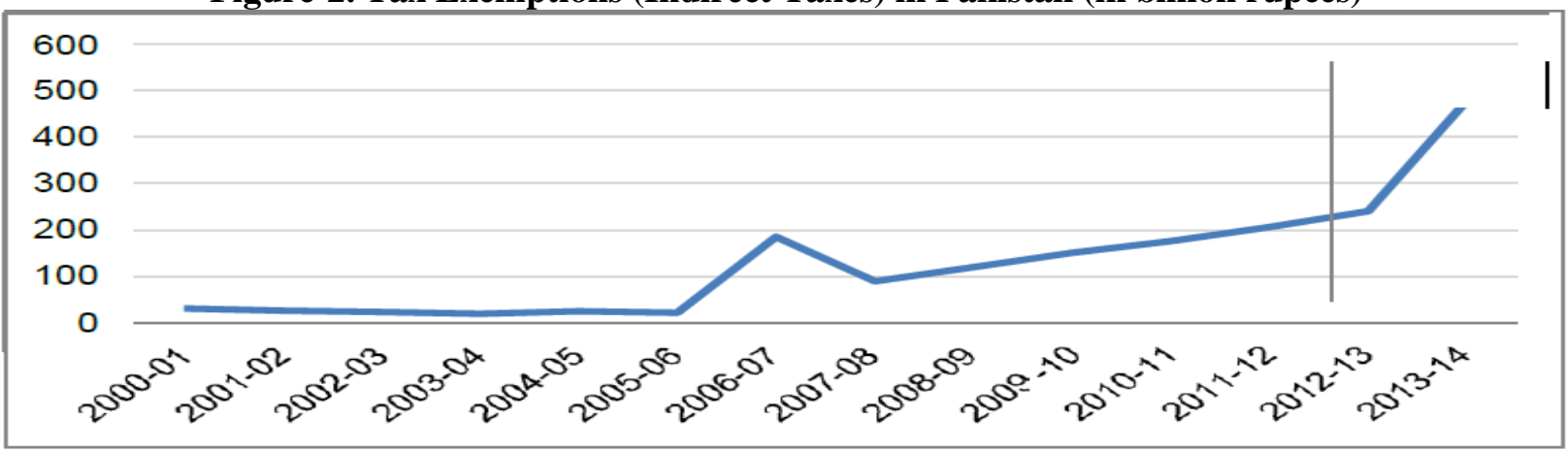

Source: Burki et al., (2015)

These tax exemptions and special treatments are commonly termed as 'tax expenditures'. The military is on the top of the list of rent-seeking actors. Others include the trading community, feudal lords, multinational companies, public sector enterprises, and parliamentarians. It is a ground reality that Pakistan is facing war on terror on multiple fronts yet enduring transparency and equity in taxation in the name of security is not justifiable.

\section{Selection of Projects and Schemes}

The return of democratic government has leveled the ground for 'constituency politics'. It was evident during the Pakistan People's Party regime, soon after 2008, the Peoples Works Program (PWP) has displayed such politics. Initially, the total budget assigned to PWP was 27 billion. In PWP, MNAs were authorized to spend this specific amount in their respective areas. The MNAs were autonomous to allocate these funds to desired projects. There was a scope of outflow of funds as self-interests of the politicians can be manifested through the selection of programs and projects. In addition, the PM as well as the federal ministers have several arbitrary allocations without the necessary action or approval. Not only federal but provincial governments had monetary allocations for the support of MPAs programs and projects. Moreover, the funds for additional development programs for provinces can also be held back and then can be used at the prudence of CM (Pasha, 2013).

In order to ensure transparency and restitution accountability, the supreme court of Pakistan has created a boundary for the discretionary power of distribution of funds. The motive behind this action was to cease the discrimination against opposition members. The government of PML-N (from 2013 to 2018) has advocated populist policies like the distribution of solar plates and laptops among youth under PM and CM schemes. Other populist PM's schemes were business loan scheme, youth training scheme, fee reimbursement scheme for less developed areas, interest-free loan scheme, youth skill development scheme, and housing scheme, and total funds allocated for these schemes were 21 billion Pakistani rupees for 2015. These schemes were popular but we're not targeting the development deficit indicators like Human capital, health care, provision of safe drinking water and sanitation, and power infrastructure on which the poor segment of the society relies the most (SDPI, 2015).

\section{FISCAL POLICY IN CHANGING LANDSCAPE: THE CASE OF CPEC}

China Pakistan Economic Corridor (CPEC), with the huge investment of 62 billion dollars from China has all geared up to bring a new face of Pakistan's economy to the rest of the world. However, a large number of policymakers and economists around the world have serious concerns about the transparency and accountability of this mega project. Besides, the sovereignty of Pakistan is also at risk as Pakistan would likely become a colony of China after the completion of the project and the foreign policy of Pakistan would be influenced by China particularly, Pakistan's relations with India (Zaidi, 2017). 
Likewise, the business models of China in other developing countries (i.e. African countries, Tajikistan and Sri Lanka) must not be ignored. China committed heavy investments in infrastructure in these economies and these economies are highly indebted and subject to criticism because of not paying debt obligations. In terms of cost-benefit analysis, the project would leave Pakistan in high debt. According to the estimates of Hassan (2016), CPEC would contribute 14 billion dollars in public debt and after three years, the amount would reach 90 billion dollars. Moreover, CPEC is under criticism in terms of inadequate fiscal measures after the World Bank report.

CPEC is a morass of the political economy of interests and needs immediate attention of authorities to resolve the controversies and ensure the stakeholders that this economic corridor would deliver on its potential. According to a World Bank report, "The CPEC, if completed, could be a gamechanger for Pakistan, but is currently mired in political economy risks" (South Asia Economic Focus Spring, 2016). As a part of political strategy, the political governments tend to avoid unpopular policies and non-populist decisions especially, the decisions related to tax imposition and power reforms (Pakistan Development Update, 2017).

For the successful implementation of CPEC and to fully reap its fruits, Pakistan needs to improve the taxation system, management of remittances, compliance, and administration, and a possible explanation for huge tax exemptions and subsidies. Political stability and fiscal harmony are also crucial for maintaining pace with ongoing terrorism and security risks (South Asia Economic Focus Spring, 2016).

\section{NECESSARY ELEMENTS FOR A JUST FISCAL POLICY}

For a just and non-politicized fiscal policy, the primary focus should be the reforms in taxation. Fiscal policy should aim to increase the direct taxes which should be progressive so that the income and wealth inequality among the different segments of the society may be reduced. The important areas to target are agriculture income, property, and capital income from financial assets. Furthermore, tax evasion and tax avoidance must also be addressed to increase the overall revenue.

Besides, rectifying the taxation system, the money transfers to the sub-national governments must be rationalized based on equity and specifically target the regional disparities. Besides, the revenue sharing scheme through NFC must also consider the regional factors despite relying heavily on a single factor like population or area only. National interests instead of personal interests, in terms of selection of projects and schemes, both at the federal and provincial level must be prioritized. Moreover, the share of development funds must focus on the sectors with maximum returns and potentials like employment creation, construction, rural development programs, and the promotion of small-scale industries. Social protection program for the general workforce, minorities, women, and poor needs special attention. Also, a reasonable amount of funds must be there to improve social services like health and education without political discrimination of area and interest.

\section{REFERENCE}

Ahmed, M., \& Baloch, A. (2014). Political economy of fiscal decentralization in Pakistan: An Analytical Study. Gomal University Journal of Research, 30(2), 28-32.

Ahmed, M., \& Khan, K. (2014). An essay on the political economy of fiscal policy making in Pakistan. International Journal of Business, Economics and Management, 1(9), 229-241.

Banful, A. B. (2011). Do formula-based intergovernmental transfer mechanisms eliminate politically motivated targeting? Evidence from Ghana. Journal of Development Economics, 96(2), 380-390.

Beatrice, H., 2017. Tax smoothing hypothesis: a case of Pakistan. In partial fulfillment of the requirements for the degree of Master of Arts in Economics, Central European University.

Burki, A. A, R. Memon \& K. Mir (2015). Multiple inequalities and policies to mitigate inequality traps in Pakistan. Oxfam and LUMS, http://policypractice.oxfam.org.uk/publications/multipleinequalities-and-policies-to-mitigate- inequality traps-in-Pakistan-346432

Caldeira, E. (2011). Does the system of allocation of intergovernmental transfers in Senegal eliminate politically motivated targeting?. Journal of African Economies, 21(2), 167-191. 
Drèze, J., \& Sen, A. (2015). An uncertain glory: India and its contradictions. Economics Books, 1. Federal Budget 2017-18. Press Brief of Budget (2017-18). Ministry of Finance, Government of Pakistan. Government of Pakistan (2014). Pakistan Economic Survey 2013-14. Islamabad, Pakistan: Finance Division, Government of Pakistan.

Hassan, A. (2016). CPEC: Macro and Micro Economic Dividends for Pakistan and the Region, IPRI, Islamabad.

Highlights of Budget 2017-18. Budget Speech 2017-18. Ministry of Finance, Government of Pakistan.

Hussain, M. \& Hussain, A. (1993). Pakistan: Problems of Governance (pp. 101-2). New Delhi: Konark Publishers.

Khawaja, I.\& Din, M. (2013). Intergovernmental transfers: an evaluation of mechanism and design of transfers in Pakistan. The Pakistan Development Review, 45-68.

Pakistan Development Update (2017). Growth: A Shared Responsibility. The World Bank.

Pasha, H. A. (2014). Progressive fiscal policy for inclusive growth. Friedrich-Ebert-Stiftung, Germany.

Pasha, H. A. (2019). Growth and Inequality in Pakistan: Agenda for Reforms. Friedrich Ebert Stiftung, Germany.

Pasha, H. A. (2013). Strategy for Tax Reforms, Federal Bureau of Revenue, Pakistan.

Qureshi, R. H. \& Ashraf, M. (2019). Water Security Issues of Agriculture in Pakistan. Pakistan Academy of Sciences (PAS), Islamabad, Pakistan, 41.

S. Ahmed, V. Ahmed \& C. O. Donoghue (2011) Reforming Indirect Taxation in Pakistan: A macro-micro analysis, Journal of Tax Research 9(2), 153-74.

State Bank of Pakistan (2010). National Finance Commissions Awards-A Review: The State of Pakistan's Economy. First Quarterly Report for FY10, Special Section 2, SBP, Pakistan.

State Bank of Pakistan (2010), Annual Report, 2010. State Bank of Pakistan. Islamabad, Pakistan.

State Bank of Pakistan (2013), Annual Report, 2012-13. State Bank of Pakistan. Islamabad, Pakistan.

SDPI (2013). Managing Intra-country Growth Disparities in South Asia, 6th South Asia Economic Summit - Theme Paper, Institute of Policy Studies, Sri Lanka.

SDPI (2015) Towards a Just and Fair Fiscal Policy in Pakistan, Issue Briefing, June 2015. OXFAM and Sustainable Development Policy Institute.

SPDC (2012) Annual Report (2011-12). Social Policy and Development Centre. Karachi Pakistan.

SPDC (2014) Annual Report (2014-15). Social Policy and Development Centre. Karachi, Pakistan.

The World Bank (2016). South Asia Economic Focus Spring. The World Bank.

The World Bank (2017). South Asia Economic Focus Spring: Globalization Backlash. The World Bank.

UNDP (2017) Water Scarcity: Pakistan's Most Critical Development Challenge. Development Advocate Pakistan, 3(4), 2017.

Zaidi, A., (2017). Has China Taken over Pakistan? (Lecture). Kolkata, West Bengal. 